Marquette University

e-Publications@Marquette

9-1-2008

The Gods of My Father Terah': Abraham the Iconoclast and the Polemics with the Divine Body Traditions in the Apocalypse of Abraham

Andrei Orlov

Marquette University, andrei.orlov@marquette.edu

Author version. Journal for the Study of the Pseudepigrapha, Volume 18, No. 1 (September 2008):

33-53. DOI. (C) 2008 SAGE Publications. Used with permission. 
NOT THE PUBLISHED VERSION; this is the author's final, peer-reviewed manuscript. The published version may be accessed by following the link in the citation at the bottom of the page.

\title{
"The Gods of My Father Terah": Abraham the Iconoclast and the Polemics with the Divine Body Traditions in the Apocalypse of Abraham
}

\author{
Andrei Orlov \\ Theology Department, Marquette University \\ Milwaukee, WI
}

\begin{abstract}
The first eight chapters of the Apocalypse of Abraham recount the early years of the young hero of the faith who is depicted as a fighter against the idolatrous practices of his father Terah. The conceptual developments found in this section of the work, especially in the depictions of the idolatrous statures, seem to play an important role in the work's overall retraction of the anthropomorphic understanding of the Deity. In the depictions of the idol BarEshath ("the Son of Fire") and some other human-like figures, whose features are vividly reminiscent of the familiar attributes of the anthropomorphic portrayals of the Deity in Ezekiel and some other biblical and pseudepigraphical accounts, one can detect a subtle polemics with the divine body traditions. The article investigates these conceptual developments in the Apocalypse of Abraham and seek to understand their place in the larger anticorporeal ideology of the Slavonic pseudepigraphon.
\end{abstract}

Journal for the Study of the Pseudepigrapha, Vol. 18, No. 1 (2008): pg. 33-53. DOI. This article is (C SAGE Publications and permission has been granted for this version to appear in e-Publications@Marquette. SAGE Publications does not grant permission for this article to be further copied/distributed or hosted elsewhere without the express permission from SAGE Publications. 
NOT THE PUBLISHED VERSION; this is the author's final, peer-reviewed manuscript. The published version may be accessed by following the link in the citation at the bottom of the page.

\section{Introduction}

It has been previously noted that the Apocalypse of Abraham exhibits subtle polemics against an anthropomorphic understanding of God. ${ }^{1}$ The second part of this pseudepigraphic text deals with Abraham's celestial ascent to the realm of the Divine Chariot. While drawing on some features of the traditional Ezekielian account of the Merkabah, ${ }^{2}$ the authors of the apocalypse appear to carefully avoid any references to anthropomorphic portrayals of the Deity, prominent in the classic prophetic account, and instead repeatedly try to depict the divine presence as the formless Voice proceeding in the stream of fire. $^{3}$

While the anti-corporeal tendencies discernable in the second, apocalyptic part of the text have already been established in previous studies, ${ }^{4}$ no sufficient explanation has been offered of how the first, haggadic part of the pseudepigraphon (chs 1-8), which depicts the patriarch as a fighter against the idolatrous statures of his father Terah, fits into the anti-anthropomorphic agenda of the text's authors.

It is possible that this haggadic portion of the apocalypse, which envisions the hero of the faith as a tester and destroyer of human-like idolatrous figures, plays a pivotal role in the anti-corporeal polemics employed by the authors of the pseudepigraphon. It does not seem coincidental that the arguments against the divine body traditions were situated in the midst of the story of the patriarch known in Jewish pseudepigraphical and rabbinic materials for his distinctive stand against idolatrous figures. It has been observed that besides the Apocalypse of Abraham other texts of the Abrahamic pseudepigrapha, such as the Testament of Abraham, also deny the possibility that God has a human-like form. Philip Munoa notes that "the Testament of Abraham studiously avoids physical description of God when describing Abraham's heavenly ascent and tours of heaven explicitly identifying God with invisible...."5 Munoa further argues that the Testament of Abraham clearly exhibits anti-anthropomorphic tendencies in highlighting God's invisibility, ${ }^{6}$ repeatedly emphasizing his unseen (a) o\&ratov) nature. ${ }^{7}$ It appears that the iconoclastic thrust of the patriarch's story, elaborated already in the Book of Jubilees, offered an ideal literary setting for the unfolding of polemics with traditions of 
divine corporeality. ${ }^{8}$ It is no coincidence that these antianthropomorphic developments also appear in the Apocalypse of Abraham, the pseudepigraphon written in the name of the hero of the faith known in Jewish lore for his opposition to idolatrous figures of the divine.

In view of these tendencies it is likely that in the distinctive depictions of Abraham's struggles with idolatrous anthropomorphic figures manufactured by his father Terah, whose features are strikingly reminiscent of the corporeal portrayals of the Deity found in the Book of Ezekiel and some other biblical and pseudepigraphical accounts, one can detect ongoing polemics with the divine body traditions. ${ }^{9}$ The purpose of this study is to explore the possible anti-anthropomorphic tendencies of the first, haggadic portion of the pseudepigraphon that might lie behind the intriguing portrayals of the patriarch as a fighter against corporeal representations of the Deity.

\section{Abraham the Iconoclast: The Background of the Imagery}

As has been previously noted, the first eight chapters of the Apocalypse of Abraham, ${ }^{10}$ a Jewish work likely composed in the early centuries of the Common Era, take the form of a midrashic exposition dealing with the early years of Abraham. ${ }^{11}$ This portion of the text depicts the young hero of the faith as a reluctant witness of the idolatrous practices of his immediate family. Such haggadic elaboration of Abraham's story is not an entire novelty created from scratch by the authors of the pseudepigraphon, but rather an important link in the chain of a long-lasting interpretive tradition attested already in the Book of Jubilees and further developed by other pseudepigraphical and rabbinic sources.

Although the Genesis account of the early years of Abraham does not elaborate his struggles with idolatry in his father's house, the story found in the Book of Jubilees provides a rather lengthy narration of such activities. Jubilees 11:16-12:14 portrays the child Abram fiercely resisting the problematic religious routines of his relatives. ${ }^{12}$ The text depicts the young hero of faith involved in extensive disputations with his father in an attempt to persuade Terah to permission has been granted for this version to appear in e-Publications@Marquette. SAGE Publications does not grant permission for this article to be further copied/distributed or hosted elsewhere without the express permission from SAGE Publications. 
abandon his abominable practices of manufacturing and serving idols. Although Abram's arguments seem to convince his father, they anger his two brothers. The account ends with Abram setting on fire the temple of idols, an event which leads to the death of Haran who perishes in flames attempting to save the statues. Although the Jubilees provides a less elaborated account of the story in comparison with the one found in the Apocalypse of Abraham, it attests to a formative initial core of the story which would be expanded or altered by subsequent pseudepigraphical and rabbinic developments. ${ }^{13}$

The rendering of the story found in the Apocalypse of Abraham appears to constitute one of the early attempts at such an extensive elaboration. The uniqueness of this account in comparison with the versions preserved in other pseudepigraphical and rabbinic materials is that the many peculiar details of the Slavonic text, including the references to the enigmatic names of various idols manufactured by Terah and their elaborate portrayals appear to be preserved only here. Yet, behind the enigmatic details one can see a persistent ideological tendency. Readers attuned to the theological reluctance of the second, apocalyptic section of the pseudepigraphon to endorse traditions of the divine form, can also detect traces of the same anti-anthropomorphic tendency in the first section of the pseudepigraphon. There, in distinctive depictions of the idols Bar-Eshath, Mar-Umath, and other human-like figures, whose features are reminiscent of the familiar attributes of the anthropomorphic portrayals of the Deity in the Book of Ezekiel and some other biblical and pseudepigraphical accounts, one can discern subtle polemics with the divine body traditions.

\section{Bar-Eshath, the Son of Fire}

One of the striking features of the text is the authors' extensive elaboration of idolatrous figures who appear in the pseudepigraphon as independent characters in fierce rivalry with other, human heroes of the text. In depictions of these idols, some of whom become known to the readers by their proper names, one can detect subtle allusions to the imagery prominent in the divine body traditions. The story involving one such idol, Bar-Eshath (Slav. Варисать), appears to stand at the center of the haggadic account of Abraham's fight against idolatry and might indeed constitute one of the most important 
nexuses in the polemical interactions with the divine body traditions found in the first part of the Apocalypse of Abraham. The story of this enigmatic figure begins in chapter five where Terah orders his son to gather wooden splinters left from the manufacturing of idols in order to cook a meal. In the pile of wooden chips Abram discovers a small figure whose forehead is decorated with the name Bar-Eshath. ${ }^{14}$ The curious young hero of the faith who doubts the power of idols decides to test the supernatural abilities of the wooden statue by putting BarEshath near the "heart of the fire." While leaving the idol near the heat Abram ironically orders him to confine the flames and, in case of emergency, to "blow on the fire to make it flare up." 15

Yet, the powers of the wooden idol fail to overcome the flames as he is not able to sustain the fiery test. Upon his return the future patriarch discovers the idol fallen with his feet enveloped in the fire and terribly burned. Abram then sees the demise of the idolatrous stature as the flames turn Bar-Eshath into a pile of dust.

Several details in this ironic account of the destroyed anthropomorphic figure that fails the test of the blazing furnace seem to point not only to the stance against idolatry but also to subtle polemics with the divine body ideologies. The first important detail is that the graphic portrayal of the anthropomorphic statue embraced by flames brings to memory familiar depictions found in the biblical theophanic accounts. In this respect it is intriguing that the authors of the Slavonic apocalypse portray the statue of a deity with his feet enveloped with fire. In Apoc. Ab. 5:9, Abram conveys that when he returned he "found Bar-Eshath fallen backwards, his feet enveloped in fire (нозь его обять огнемь) ${ }^{16}$ and terribly burned." 17 This detail invokes an important theophanic feature often found in several visionary accounts where the anthropomorphic figure of the Deity is depicted with fiery feet or a fiery lower body.

For example, in the paradigmatic vision recounted in Ezekiel 1, where the seer beholds the anthropomorphic Kavod, he describes the fiery nature of the lower body of the Deity. Ezek. 1:27 reads:

I saw that from what appeared to be his waist up he looked like glowing metal, as if full of fire, and I saw that from what appeared to be his waist down he looked like fire (\#) permission has been granted for this version to appear in e-Publications@Marquette. SAGE Publications does not grant permission for this article to be further copied/distributed or hosted elsewhere without the express permission from SAGE Publications. 
NOT THE PUBLISHED VERSION; this is the author's final, peer-reviewed manuscript. The published version may be accessed by following the link in the citation at the bottom of the page.

h)rmk yty)r h+mlw wyntm h)rmmw); and brilliant light surrounded him....

A similar depiction can be also found in Ezekiel 8:2 where a visionary again encounters the celestial anthropomorphic manifestation with fiery loins:

I looked, and there was a figure that looked like a human being; below what appeared to be its loins it was fire, and above the loins it was like the appearance of brightness, like gleaming amber.

Another important testimony to this prominent motif can be found in the first chapter of the Book of Revelation, a text possibly contemporaneous with the Apocalypse of Abraham, which in many aspects shares the theophanic paradigm of the Book of Ezekiel and the Book of Daniel. ${ }^{18}$ Rev. 1:15 reads:

His head and his hair were white as white wool, white as snow; his eyes were like a flame of fire, and his feet were like burnished bronze, refined as in a furnace (kai. oi po, dej auvtou/ o[moioi calkoliba, nw | w’j evn kami, nw pepurwme, nhj), and his voice was like the sound of many waters....19

It is apparent that the tradition found in the Book of Revelation is related to the one found in the Apocalypse of Abraham since it refers to the feet of the Deity "refined as in a furnace," a feature which might implicitly point to the theophanic traditions of the fiery test, that will be explored in detail later in our study.

For now, we will focus on another portentous detail of the aforementioned passage found in the Book of Revelation, which might also be linked to the conceptual developments found in the Apocalypse of Abraham. This feature concerns the title of the anthropomorphic divine manifestation with fiery feet, a figure whom the Book of Revelation designates using the expression "like a son of man" (o[moion ui $\circ . n$ avngrw, pou). This enigmatic designation deserves special attention. It is no secret that the son of man figure represents an important conceptual locus in the Second Temple anthropomorphic ideologies. This portentous title, which is well known from the Book of permission has been granted for this version to appear in e-Publications@ Marquette. SAGE Publications does not grant permission for this article to be further copied/distributed or hosted elsewhere without the express permission from SAGE Publications. 
Daniel, the Similitudes of Enoch, 4 Ezra and New Testament materials, was often used to label the luminous anthropomorphic manifestations of the Deity. It is possible that this title invokes subtle allusions to the name of the wooden idol of the Slavonic apocalypse.

One should recall that the Apocalypse of Abraham 5:5 mentions that the idol that the patriarch discovered among the wooden chips in the house of his father was labeled on his forehead as "god BarEshath." 20 Scholars have proposed a Semitic background for this enigmatic name, tracing it to the Aramaic expression () ) t\#) rb "the son of fire." This connection was first noticed by Louis Ginzberg ${ }^{21}$ and recently was supported and investigated in depth by Alexander Kulik. Kulik links the origin of the title $t \#$ ) rb to Mesopotamian traditions of the deities of fire noting that their names were often rendered into Greek by several terminological designations including the Greek word fwv. ${ }^{22}$

Kulik's reference to the Greek term $\mathrm{fwv}$ is intriguing since the term was often used in Jewish theophanic traditions to designate the glorious anthropomorphic manifestations or replicas of the Deity, including the luminous extent of the Protoplast often depicted in such accounts as the celestial Anthropos. These traditions often play on the ambiguity of the term which, depending on accent, can designate either $f_{\mathrm{w} \& \mathrm{~V}}$ "a man" or $\mathrm{fw}_{\mathrm{w} \sim \mathrm{v}}$ "light," pointing both to the luminous and anthropomorphic nature of the divine body. ${ }^{23}$ It seems that the authors of the Apocalypse of Abraham might also be cognizant of this correlation of man/light when in Apoc. $A b .23: 10$ they choose to label the Protoplast as the light of men (свьть чл(о)в(ь)чь). ${ }^{24}$ It is possible that the play on $\mathrm{fwv}_{\mathrm{wV}}$ terminology could again be manifested in this enigmatic expression from the Slavonic apocalypse, whose Semitic original many scholars have argued underwent a Greek stage of transmission. In view of these peculiar terminological correlations, is it possible that in the name Bar Eshath (the "Son of Fire") the play on the ambiguous fwv terminology might be present? If so, how could this hypothetical terminological correspondence uniting luminosity and anthropomorphism find its Semitic expression in the original textual framework of the Slavonic apocalypse? In this respect it should be noted that besides the pun on the Greek word fwv (man/light) some scholars of Jewish theophanic traditions propose the possibility of permission has been granted for this version to appear in e-Publications@Marquette. SAGE Publications does not grant permission for this article to be further copied/distributed or hosted elsewhere without the express permission from SAGE Publications. 
another, Semitic pun on \#)/\#y) (fire/man) ${ }^{25}$ which might already be manifested in Ezek 8:2. ${ }^{26}$ It appears that Ezekelian terminological interplay intensifies the connections between the fiery and anthropomorphic characteristics of the divine Extent. In view of these terminological links it is possible that by naming the anthropomorphic idol as the Son of Fire the authors of the Slavonic apocalypse might have sought to engage the interplay with another prominent Aramaic designation which stands at the centre of Jewish anthropomorphic developments, the title "Son of Man" (\#n) rb) which linguistically is very similar to t\#) rb.

Our ongoing research will demonstrate that the authors of the Slavonic apocalypse were very familiar with Adamic lore, ${ }^{27}$ the mediatorial stream where the correlations between light/man or fire/man were first developed. In view of these developments the possibility of the pun on words "fire" and "man" in the title of BarEshath cannot be completely excluded.

\section{Testing by the Fire}

It is time to return to the motif of the fiery test that turned our wooden idol into a pile of dust. The Apocalypse of Abraham 7:2 reminds its readers that fire "mocks with its flames the things which perish easily." 28 It appears that the early biblical and extra-biblical testimonies to this tradition of the fiery test hint at the fact that this motif might have originated within anthropomorphic currents. From them one learns that the divine body traditions have their own use of the fiery testing - its purpose is to underline the distinction between true and false representations of the Deity where the divine form's endurance against the element of fire testifies to its authenticity. This theological conviction that the celestial bodies are somehow not consumed by fire and may even be composed of the fiery substance can be found in several places in the Apocalypse of Abraham where fiery imagery is often employed in portrayals of divine and angelic manifestations. ${ }^{29}$ Moreover it appears that the authors of the Slavonic apocalypse believe that fire represents the substance that surrounds the very presence of the Deity. ${ }^{30}$ Here the authors of the Apocalypse of Abraham are drawing on the established visionary tradition already manifested in several biblical accounts, including Exodus' theophany of permission has been granted for this version to appear in e-Publications@Marquette. SAGE Publications does not grant permission for this article to be further copied/distributed or hosted elsewhere without the express permission from SAGE Publications. 
the burning bush, where the son of Amram encounters the celestial manifestation enveloped by fire but not consumed by its flames. The motif of the celestial form embraced by fire also brings to memory another, already mentioned paradigmatic account found in the first chapter of the Book of Ezekiel, where the seer beholds the divine anthropomorphic extent enveloped by fire or perhaps even composed of it. It is also intriguing that in some Second Temple apocalyptic materials the divine corporealities endure a test of the blazing furnace very similar to the one that destroys the wooden "body" of Bar-Eshath in the Apocalypse of Abraham. One of the distinctive specimens of such a tradition can be found in Daniel 3, a composition well known for its promulgation of anthropomorphic ideologies. There one can find an elaborate account depicting the appearance of the divine corporeal manifestation in the blazing furnace. In Daniel, the story of the fiery test finds its place, as it does in the Apocalypse of Abraham, in the midst of debates about the essence of true and false (idolatrous) representations of the Deity. There, Nebuchadnezzar orders to put into the furnace of the blazing fire three Israelite youth - Shadrach, Mashach, and Abednego, who refused to worship the golden idol of the king. In the course of the fiery test these three men are rescued by the divine manifestation ${ }^{31}$ which miraculously appears in the midst of fire. Commentators of this tradition have noted that the Aramaic text preserves the mystery of the divine presence in the furnace and does not reveal the identity of the divine manifestation. However, the authors of the Greek version of Daniel 3 fill the exegetical lacunae by recounting the story of the angel of the Lord descending into the furnace in order to rescue the three faithful Jews. ${ }^{32}$ It is clear that this divine corporeality unharmed by the fiery test is polemically juxtaposed in the text with the idolatrous "image" of the king and appears to be understood as a "statue" superior to the idol created by Nebuchadnezzar. The fiery test of the human bodies of Shadrach, Mashach, and Abednego, who endure the deadly flames along with the divine form, is also noteworthy. The imagery of the blazing furnace in Daniel 3 appears to represent an important theophanic locus where the human corporealities are able to encounter the divine extent in the midst of fire. Choon Leong Seow underlines this important theophanic aspect of the passage when he remarks that "the Jews do not only survive the ordeal, they even encounter divine presence in the fire ordeal." ${ }^{33}$ He further notes that 
the narrator does not say that the four individuals are walking in the furnace, but that they are walking amid the fire... the story is that they are with a divine being in the midst of the fire. They encounter divine presence in the middle of the fire. Here, as often in the Old Testament, fire is associated with the presence of God. On Mount Sinai, the presence of God was accompanied by, perhaps even made manifest by, the appearance of fire (Exod. 19:16, 19; 20:18, 21) and in Israel's hymnody fire is often associated with the manifestation of God (e.g., Pss. 18:8$16 ; 77: 17-20) \ldots{ }^{34}$

In this respect the evidence found in Daniel 3 appears to represent a link in a long-lasting development within the divine body traditions in which several distinguished individuals, including the patriarch Enoch or the prophet Moses, were depicted as enduring the fiery test of the encounter with the dangerous divine extent emitting light and fire. In the course of this deadly encounter these human exemplars often undergo a radical transformation, acquiring for themselves fiery luminous corporealities ${ }^{35}$ or "faces." The traditions thus envision these figures as representations of the Deity and even as closely associated with the divine Kavod itself.

The authors of the Slavonic apocalypse appear to be cognizant of these theophanic currents when in the story of Bar-Eshath they choose fire as the testing ground for the authenticity of the anthropomorphic figure representing a deity. The Danielic background of the fiery test's motif ${ }^{36}$ seems to be also implicitly reaffirmed in the final destiny of Terah (in Jubilees - Haran) who in the Apocalypse of Abraham 8 perishes in the fire along with his household and idols. ${ }^{37}$ These members of Abraham's family, unlike Shadrach, Mashach, and Abednego, share the same destiny as idolatrous anthropomorphic figures whom God also turns into piles of ashes.

It has already been noted that, despite the apparent antianthropomorphic thrust of the Slavonic pseudepigraphon, the symbolism of fire, so prominent in the biblical theophanies, was not completely abandoned by the authors of the Apocalypse of Abraham, who repeatedly choose to portray the divine presence through the imagery of the Voice coming in the stream of fire. Here one can see the formative influence of the Deuteronomic tradition with its

Journal for the Study of the Pseudepigrapha, Vol. 18, No. 1 (2008): pg. 33-53. DOI. This article is C SAGE Publications and permission has been granted for this version to appear in e-Publications@Marquette. SAGE Publications does not grant permission for this article to be further copied/distributed or hosted elsewhere without the express permission from SAGE Publications. 
promulgation of an aural rather than corporeal manifestation of the Deity. ${ }^{38}$

Nevertheless, the symbolism of fire does not remain entirely unambiguous in the Slavonic apocalypse, and it is possible that there one encounters subtle polemics even against this theophanic element prominent in the corporeal ideologies. Thus, although the Apocalypse of Abraham also reaffirms the language of fire in its theophanic depiction of the divine Voice, in the patriarch's speech about the hierarchy of natural elements found in chapter 7 the fire occupies the lowest grade being easily "subdued" by water, the next element in the hierarchy:

Fire is the noblest [element] in the image [of the world], since even the things which are [otherwise] unsubdued are subdued in it, and [since it mocks with its flames the things which are perish easily. <But I would not call it a god either, since it is subjugated to water. $>$ Water is indeed nobler, since it overcomes fire and soaks the earth (Apoc. $A b .7: 2-4) .{ }^{39}$

\section{Mar-Umath, the One Who is "Heavier than Stone"}

Our study has suggested that the authors of the Slavonic apocalypse appear to be involved in polemics with the divine body traditions by consciously deconstructing theophanic imagery and even technical vocabulary distinctive to the classic anthropomorphic developments. Further support for this hypothesis can be found in the peculiar conceptual elaborations involving another problematic figure of the story - a statue of the stone idol Mar-Umath.

Although the idols produced by Terah are said to be made of gold, silver, copper, iron, wood, stone and other unanimated materials, the authors of the text refer to them as the "bodies" (Slav. тьла). In view of our previous research pointing to the possibility of polemics with the divine body traditions, this use of "corporeal" terminology does not appear coincidental. It is also intriguing that the context where this corporeal terminology is applied in the apocalypse implicitly invokes the account of creation, an important biblical locus which promulgates anthropomorphic priestly ideology. This creational topos shaped by a corporeal motif also appears to be polemically 
refashioned by the authors of the Slavonic apocalypse. In this new polemical framework, Abraham's father Terah now assumes the place of God and posits as a "creator" of the idolatrous "bodies," a role reminiscent of the protological position of the Deity who once shaped the body of the first human after the likeness of his own image. Thus in $A p o c$. $A b .6: 2-3$ the following passage can be found:

And I [Abraham] said, "How can the creation of the body (створеніе тьла) (of the idols) made by him (Terah) be his helper? Or would he have subordinated his body (тьло) to his soul, his soul to his spirit, then his spirit - to folly and ignorance?"40

It is remarkable that the text tells about the "creation of the body" (створеніе тьла) of the idols, thus clearly applying corporeal terminology to the inanimate objects. More intriguing is that the "corporealities" of the idols, similar to the Genesis account, are placed in an unambiguous connection to the corporeality (Тьло) of their master and creator - the craftsman Terah. As it is common in the divine body tradition, the passage also makes an explicit terminological connection between the body of the Master and its corporeal replica.

The terminological choice involving the word "creation" (створеніе) also does not seem coincidental but rather serves as an important pointer to the protological biblical counterpart. In $A p o c$. $A b$. $6: 7$ this term is used again in relation to the idol Mar-Umath. ${ }^{41}$

It has already been noted that, like the account of Bar-Eshath, the story of the stone idol Mar-Umath appears to represent another important nexus in the text where polemical interactions with the divine body traditions unfold in the midst of already familiar imagery.

In the Apocalypse of Abraham 1:3-4 the following description of this stone idol is found:

I, Abraham, having entered their temple for the service, found a god named Mar-Umath, carved out of stone, fallen at the feet of an iron god, Nakhon. And it came to pass, that when I saw this, my heart was troubled. And I fell to thinking, because I, permission has been granted for this version to appear in e-Publications@ Marquette. SAGE Publications does not grant permission for this article to be further copied/distributed or hosted elsewhere without the express permission from SAGE Publications. 
Abraham, was unable to return him to his place all by my self, since he was heavier (тяжекъ) than a great stone. ${ }^{42}$

It is possible that the description of Mar-Umath in this passage invokes the technical terminology of the Kavod paradigm.

This terminological link with the divine body traditions pertains to the designation of Mar-Umath as "being heavier that a great stone." The Slavonic term used here for the word "heavy" - "тяжекъ" арреars to be an allusion to the technical terminology reserved for the designation of the divine Glory (Kavod) in Ezekelien and priestly materials. There the quality of "heaviness" serves as one of the meaning of the Hebrew word Kavod. ${ }^{43}$ It appears that the authors of the Slavonic apocalypse know this facet of this term's meaning and even use it interchangeably for Kavod in another passage found in the Apocalypse of Abraham.

Ryszard Rubinkiewicz has argued that the Slavonic term for "heaviness"44 (Slav. тягота) found in another passage Apoc. Ab. 14:13 serves as a technical term for rendering the Hebrew Kavod. Apoc. $A b$. 14:13 reads: "....Since God gave him [Azazel] the heaviness (тяготоу) and the will against those who answer him...."45

Rubinkiewicz notes that the original text most likely had dwbk, which has the sense of "gravity," but also of "glory," and the meaning of the verse would be: "the Eternal One ... to him he gave the glory and power." According to Rubinkiewicz, this ambiguity lays at the basis of the Slavonic translation of the verse. ${ }^{46}$

If the term "heaviness" is indeed associated in the mind of the Apocalypse of Abraham's authors with the Kavod terminology, it is intriguing that this notion was used solely in the description of the negative protagonists of the text - the stone idol Mar-Umath and the fallen angel Azazel. Such usage might again point to the polemical stance of the authors of the pseudepigraphon against the Kavod tradition with its peculiar theophanic imagery. permission has been granted for this version to appear in e-Publications@Marquette. SAGE Publications does not grant permission for this article to be further copied/distributed or hosted elsewhere without the express permission from SAGE Publications. 


\section{"A Likeness of the a Craftsman's Work"}

Another important facet of the anti-anthropomorphic thrust of the conceptual deliberations detected in the Slavonic apocalypse pertains to their polemical appropriation of the "likeness" language which often permeates the conceptual core of corporeal theophanic traditions. One will recall that in the paradigmatic theophanic priestly template reflected in the Book of Ezekiel and the first chapter of the Book of Genesis, the language of "likeness" comes to the fore. The authors of the Book of Ezekiel repeatedly strive to describe their vision of the divine and angelic phenomena through the language of "likeness." The same tendency is discernable in Genesis 1 where the Deity creates humans in the likeness of his image.

The formulae of "likeness" also looms large in the Apocalypse of Abraham, but the text's authors use it in a distinctively polemical way. Thus in chapter 25 of the apocalypse, God offers to the seer the vision of the future Temple polluted by the idol of jealousy, an appearance which is conveyed through the language of likeness:

I saw there the likeness of the idol of jealousy (подобие идола ревнования), as a likeness (подобие) of a craftsman's [work] such as my father made, and its stature was of shining copper, and a man before it, and he was worshiping it; and [there was] an altar opposite it and youth were slaughtered on it before the idol. And I said to him, "What is this idol, and what is the altar, and who are those being sacrificed, and who is the sacrificer, and what is the beautiful temple which I see, art and beauty if your glory that lies beneath your throne?" And he said: "Hear Abraham! This temple and altar and the beautiful things which you have seen are my image of the sanctification of the name of my glory (святительства имени славы моея), where every prayer of men will dwell, and the gathering of kings and prophets, and the sacrifice which shall establish to be made for me among my people coming from your progeny. And the stature you saw is my anger, because the people who will come to me out of you will make me angry. And the man you saw slaughtering is he who angers me. And the sacrifice is the murder of those who are for me a testimony of the close of judgment in the end of the creation (Apoc. $A b .25: 1-6) .{ }^{47}$ 
In this pivotal passage the earlier motifs that readers of the apocalypse encountered in the first section of the pseudepigraphon dealing with the idolatrous practices of Abraham's father become explicitly invoked. The statues similar to those made in the house of Terah ("a likeness (подобие) of a craftsman's [work] such as my father made") are now installed in God's Temple. This idolatrous practice of worshiping the statue of shinning copper, labeled in the story as "a likeness (подобие) of a craftsman's work," seems to cautiously invoke the language of "likeness" known from the priestly theophanic paradigm exemplified in Genesis 1:26 and Ezekiel 1. This reference to "craftsman" invokes again the story of Terah and his creation of the idols. The tendency to label the idolatrous figures as "bodies," already detectable in the early chapters, is again reaffirmed here. The idolatrous practices are then contrasted to true worship which is described in the now familiar language of the aural paradigm of the divine name that denies that the deity can possess a body. Thus the future eschatological temple is portrayed as a dwelling place, not for the abominable shining statue, but for "the image of the sanctification of the name of my [God's] glory (святительства имени славы моея), where every prayer of men will dwell (в нюже вселится всяка молба мужьска)." ${ }^{48}$ It is apparent that the authors try to re-interpret the technical terminology of the divine Glory tradition by merging it with formulae borrowed from the Shem ideology. There is also no doubt that the authors' attitude to the anthropomorphic ideology remains polemical which is unabashedly shown in labeling the shining statue as the idol of jealousy.

\section{Conclusion}

The elaboration of the story of Abraham's struggle against idols found in the Slavonic apocalypse provides unique insight into the complex world of the Jewish liturgical debates in the early centuries of the Common Era. It was a time when, faced with a wide array of challenges involving the loss of the terrestrial sanctuary, the authors of the Jewish apocalyptic writings tried to embrace other theological alternatives for preserving and perpetuating traditional sacerdotal practices. ${ }^{49}$ One such viable tradition was connected with the idea of the celestial sanctuary represented by the divine Chariot. 
Of course the concept of the heavenly temple as the locus of liturgical and mystical experience was not an entirely novel development but rather the legacy of the complex theological climate of the Second Temple period when various sacerdotal groups and clans competed for the primacy and authority of their priestly legacy by looking for alternative sacerdotal practices involving the heavenly counterpart of the terrestrial temple. This contention-ridden sacerdotal environment created a whole gallery of ideal priestly figures, including Michael, Yahoel, Enoch, Melchisedek, and Levi, who were depicted as distinguished servants of celestial sanctuaries. In this respect the story of the young hero of the faith who travels from the destroyed terrestrial sanctuary polluted by the idols of his father to the heavenly temple is not an invention of the authors of the Apocalypse of Abraham but rather is one of the links in the established literary and mystical tradition attested already in the early booklets of 1 Enoch where the seventh antediluvian patriarch ascends to the heavenly temple in order to behold the divine The difference here, however, is that while trying to embrace the liturgical and sacerdotal significance of the journey to the heavenly sanctuary, the authors of the Slavonic apocalypse at the same time appear to be quite reluctant to embrace the visual praxis of the Enochic paradigm and its anthropomorphic tenets. Instead, another, aural praxis involving revelation of the divine Voice and veneration of the divine Name unfolds. Such polemical interaction between two prominent conceptual trends involving the idea of the celestial temple might provide important insights for understanding the character of later Merkabah and Hekhalot developments where the traditions about the divine Form and the divine Name appear to undergo creative conflation.

\section{Notes}

${ }^{1}$ C. Rowland, "The Vision of God in Apocalyptic Literature," JSJ 10 (1979) 137-154; idem, The Open Heaven: A Study of Apocalyptic in Judaism and Early Christianity (New York: Crossroad, 1982) 86-87; A. Orlov, "Praxis of the Voice: The Divine Name Traditions in the Apocalypse of Abraham," JBL 127.1 (2008) 53-70; idem, "The Pteromorphic Angelology of the Apocalypse of Abraham," CBQ (forthcoming).

2 Scholars previously noted that the seer's vision of the divine throne found in the Apocalypse of Abraham "draws heavily on Ezekiel and stands directly in the tradition of Merkabah speculation." J. Collins, The Apocalyptic Imagination: An Introduction to Jewish Apocalyptic Literature (2nd ed.;

Journal for the Study of the Pseudepigrapha, Vol. 18, No. 1 (2008): pg. 33-53. DOI. This article is C SAGE Publications and permission has been granted for this version to appear in e-Publications@Marquette. SAGE Publications does not grant permission for this article to be further copied/distributed or hosted elsewhere without the express permission from SAGE Publications. 
NOT THE PUBLISHED VERSION; this is the author's final, peer-reviewed manuscript. The published version may be accessed by following the link in the citation at the bottom of the page.

Grand Rapids: Eerdmans, 1998) 183. See also I. Gruenwald, Apocalyptic and Merkavah Mysticism (AGAJU 14; Leiden: Brill, 1980) 55-57; Rowland, Open Heaven, 86-87.

${ }^{3}$ In his comparative analysis of the accounts from Ezekiel and the Apocalypse of Abraham, Rowland demonstrates that the author of the Slavonic apocalypse, while preserving the angelic depictions of the Ezekiel's account, carefully avoids the anthropomorphic description of the Kavod, substituting it with the reference to the Divine voice. Rowland concludes that "there appears here to have been a deliberate attempt made to exclude all reference to the human figure mentioned in Ezekiel 1." Rowland, The Open Heaven, 87.

${ }^{4}$ See Orlov, "Praxis of the Voice," 53-70.

${ }^{5}$ P. Munoa in Early Jewish and Christian Mysticism. A Collage of Working Definitions (forthcoming).

${ }^{6}$ Here the constraints on the visual representation of the deity is even more demanding than in the Apocalypse of Abraham, since the authors of the Testament of Abraham render the Deity as completely invisible, lacking any visible representation.

7 Munoa illustrates these tendencies by referring to the passage from chapter 16 where the following tradition about the invisibility of God can be found: "When Death heard, he shuddered and trembled, overcome by great cowardice; and he came with great fear and stood before the unseen Father, shuddering, moaning and trembling, awaiting the Master's demand. Then the unseen God said to Death...." (T. Abr. 16:34). P. Munoa, Four Powers in Heaven: The Interpretation of Daniel 7 in the Testament of Abraham (JSPSup 28; Sheffield: Sheffield Academic Press, 1998) 141.

${ }^{8}$ For the background of the story of Abraham as a fighter with idols in the Book of Jubilees and the later rabbinic materials (Genesis Rabbah 38:13, Tanna debe Eliahu 2:25, Seder Eliahu Rabba 33), see: Box and Landsman, The Apocalypse of Abraham. Edited, with a Translation from the Slavonic Text and Notes, 88-94; Rubinkiewicz, L'Apocalypse $d^{\prime}$ Abraham en vieux slave. Introduction, texte critique traduction et commentaire, 43-49.

${ }^{9}$ For the discussion of the divine body traditions in biblical, pseudepigraphical, and rabbinic materials see Andrei A. Orlov, The Enoch-Metatron Tradition (TSAJ, 107; Tübingen: Mohr/Siebeck, 2005) 143-146; 211 252; idem, "'Without Measure and Without Analogy': The Tradition of the Divine Body in 2 (Slavonic) Enoch," in A. Orlov, From Apocalypticism to Merkabah Mysticism: Studies in the Slavonic Pseudepigrapha (JSJSup., 114; Leiden: Brill, 2007) 149-174.

10 On the date and provenance of the Apocalypse of Abraham, see: G. H. Box and J.I. Landsman, The Apocalypse of Abraham. Edited, with a

Journal for the Study of the Pseudepigrapha, Vol. 18, No. 1 (2008): pg. 33-53. DOI. This article is C SAGE Publications and permission has been granted for this version to appear in e-Publications@Marquette. SAGE Publications does not grant permission for this article to be further copied/distributed or hosted elsewhere without the express permission from SAGE Publications. 
NOT THE PUBLISHED VERSION; this is the author's final, peer-reviewed manuscript. The published version may be accessed by following the link in the citation at the bottom of the page.

Translation from the Slavonic Text and Notes (TED, 1.10; London, New York: The Macmillan Company, 1918) xv-xix; B. Philonenko-Sayar and M. Philonenko, L'Apocalypse d'Abraham. Introduction, texte slave, traduction et notes (Semitica, 31; Paris, 1981) 34-35; R. Rubinkiewicz, "Apocalypse of Abraham," The Old Testament Pseudepigrapha (ed. J. H. Charlesworth; New York: Doubleday, 1985 [1983]) 1.681-705 at 683; idem, L'Apocalypse d'Abraham en vieux slave. Édition critique du texte, introduction, traduction et commentaire (Towarzystwo Naukowe Katolickiego Uniwersytetu Lubelskiego: Źródła i monografie, 129; Lublin, 1987) 70-73; Alexander Kulik, "К датировке 'Откровения Авраама'" ["About the Date of the Apocalypse of Abraham"], In Memoriam of Ja. S. Lur'e (eds. N.M. Botvinnik and Je. I. Vaneeva; St. Petersburg, 1997), 189-95; idem, Retroverting Slavonic Pseudepigrapha, 2-3.

${ }^{11}$ For the published Slavonic manuscripts and fragments of the $A p o c$. $A b$., see Ioan Franko, "Книга о Аврааме праотци и патриарси" ["The Book about the forefather and the patriarch Abraham"], in Апокріфи $i$ легенди з украінських рукописів [The Apocrypha and the Legends from the Ukrainian Manuscripts] (5 vols.; Monumenta Linguae Necnon Litterarum Ukraino-Russicarum [Ruthenicarum] 1-5; L'vov, Schevchenka, 1896-1910), 1:80-86; Alexander I. Jacimirskij, "Откровение Авраама" ["The Apocalypse of Abraham"], in Библиографический обзор апокрифов в южнославянской и русской письменности (Списки памятников) Выпуск 1. Апокрифы ветхозаветные [The Bibliographical Survey of Apocryphal Writings in South Slavonic and Old Russian Literature. Vol. 1. The Old Testament Pseudepigrapha] (Petrograd, The Russian Imperial Academy of Sciences, 1921), 99-100; P. P. Novickij, ed., "Откровение Авраама" ["The Apocalypse of Abraham"], in Общество любителей древней письменности [The Society of Lovers of Ancient Literature] 99.2 (St. Petersburg, Markov, 1891); Ivan Ja. Porfir'ev, "Откровение Авраама" ["The Apocalypse of Abraham"], in Апокрифические сказания o ветхозаветных лицах и событиях по рукописям соловецкой библиотеки [The Apocryphal Stories about Old Testament Characters and Events according to the Manuscripts of the Solovetzkoj Library] (Sbornik Otdelenija russkogo jazyka i slovesnosti Imperatorskoj akademii nauk 17.1; St. Petersburg, The Russian Imperial Academy of Sciences, 1877), 111-30; Philonenko-Sayar and Philonenko, L'Apocalypse d'Abraham, 36-105; Alexander N. Pypin, Ложные и отреченные книги славянской и русской старины. Памятники старинной русской литературы, издаваемые графом Григорием Кушелевым-Безбородко Том 3 [The False and Rejected Books of Slavonic and Russian Antiquity. Memorials of Ancient Russian Literature edited by Count Gregory Kushelev-Bezborodko Vol. 3](St. Petersburg:

Journal for the Study of the Pseudepigrapha, Vol. 18, No. 1 (2008): pg. 33-53. DOI. This article is (C SAGE Publications and permission has been granted for this version to appear in e-Publications@Marquette. SAGE Publications does not grant permission for this article to be further copied/distributed or hosted elsewhere without the express permission from SAGE Publications. 
NOT THE PUBLISHED VERSION; this is the author's final, peer-reviewed manuscript. The published version may be accessed by following the link in the citation at the bottom of the page.

Kulesh, 1860-62), 24-36; Rubinkiewicz, L'Apocalypse d'Abrahamen vieux slave, 98-256; Izmail I. Sreznevskij, "Книги Откровения Авраама" [The Apocalypse of Abraham], in Известия Императорской академии наук по отделению русского языка и словесности. Том 10 [Proceedings of the Imperial Academy of Sciences. Division of Russian Language and Literature. Vol. 10] (St. Petersburg: Russian Academy of Sciences, 1861-63), 648-665; Nikolaj S. Tihonravov, Памятники отреченной русской литературы [Memorials of Russian Apocryphal Literature] (2 vols.; St. Petersburg/Moscow: Obschestvennaja Pol'za, 1863), 1:32-77. For the translations of the Apoc. Ab., see Nathanael Bonwetsch, Die Apokalypse Abrahams: Das Testament der vierzig Märtyrer (Studien zur Geschichte der Theologie und der Kirche, Bd.1, Heft 1; Leipzig: Deichert, 1897); Box and Landsman, Apocalypse of Abraham, 35-87; Mario Enrietti and Paolo Sacchi, "Apocalisse di Abramo," in Apocrifi dell'Antico Testamento (ed. Paolo Sacchi et al.; 5 vols.; Turin/Brescia: Unione tipografico-editrice torinese, 1981-97), 3:61-110; Kulik, Retroverting Slavonic Pseudepigrapha, 9-35; A. Pennington, "Apocalypse of Abraham," AOT, 363-491; Donka Petkanova, "Откровение на Авраам" ["The Apocalypse of Abraham"], in Старобългарска Есхатология. Антология [Old Bulgarian Eschatology. Anthology] (ed. D. Petkanova and A. Miltenova; Slavia Orthodoxa; Sofia: Slavica, 1993), 17-30; Belkis Philonenko-Sayar and Marc Philonenko, "Die Apokalypse Abrahams," JSHRZ 5.5 (Gutersloh: Mohn, 1982), 413-60; Paul Rie.ler, "Apokalypse des Abraham," in Altjüdisches Schriftum außerhalb der Bibel (Freiburg: F. H. Kerle, 1928), 13-39; 1267-69; Rubinkiewicz, "Apocalypse of Abraham," OTP 1:681-705; idem, "Apocalypsa Abrahama," in Apokryfy Starego Testamentu (ed. R. Rubinkiewicz; Warsaw: Oficyna Wydawnicza "Vocatio," 1999), 460-81.

12 "The child [Abram] began to realize the errors of the earth - that everyone was going astray after the statues and after impurity. His father taught him (the art of) writing. When he was two weeks of years [= 14 years], he separated from his father in order not to worship idols with him. He began to pray to the creator of all that would save him from the errors of mankind and that it might not fall to his share to go astray after impurity and wickedness...... During the sixth week, in its seventh year, Abram said to his father Terah: 'My father.' He said: 'Yes, my son?' He said: 'What help and advantage do we get from these idols before which you worship and prostrate yourself? For there is no spirit in them because they are dumb. They are in error of the mind. Do not worship them. Worship the God of heaven who makes the rain and dew fall on earth and makes everything on earth. He created everything by his word; and all life (comes) from his presence. Why do you worship those things have no spirit in them? For they are made by hands and you

Journal for the Study of the Pseudepigrapha, Vol. 18, No. 1 (2008): pg. 33-53. DOI. This article is C SAGE Publications and permission has been granted for this version to appear in e-Publications@Marquette. SAGE Publications does not grant permission for this article to be further copied/distributed or hosted elsewhere without the express permission from SAGE Publications. 
NOT THE PUBLISHED VERSION; this is the author's final, peer-reviewed manuscript. The published version may be accessed by following the link in the citation at the bottom of the page.

carry them on your shoulders. You receive no help from them, but instead they are a great shame for those who make them and an error of the mind for those who worship them. Do not worship them.' Then he said to him: 'I, too, know (this), my son. What shall I do with the people who have ordered me to serve in their presence? If I tell them what is right, they will kill me because they themselves are attached to them so that they worship and praise them. Be quite, my son, so that they do not kill you.' When he told these things to his two brothers and they became angry at him, he remained silent...... In the sixtieth year of Abram's life (which was the fourth week in its' fourth year), Abram got up at night and burned the temple of the idols. He burned everything in the temple but no one knew (about it). They got up at night and wanted to save their gods from the fire. Haran dashed in to save them, but the fire raged over him. He was burned in the fire and died in Ur of the Chaldeans before his father Terah. They buried him in Ur of the Chaldeans." J.C. VanderKam, The Book of Jubilees (2 vols.; CSCO 51011, Scriptores Aethiopici 87-88; Leuven: Peeters, 1989) 2. 67-70.

${ }^{13}$ It should be noted that the subtle allusions to the traditions of the divine form might already be hinted at in the account found in the Jubilees which attempts to depict Terah as the priestly figure serving in the "presence of the statures." One of the intriguing parallels here is that similar to the Living Creatures (the Hayyot) predestined to carry on their shoulders the divine anthropomorphic extent in the classic Ezekelien account, Terah too carries the idolatrous statures on his shoulders.

${ }^{14}$ Kulik, Retroverting Slavonic Pseudepigrapha, 12.

15 Kulik, Retroverting Slavonic Pseudepigrapha, 12-13.

16 B. Philonenko-Sayar and M. Philonenko, L'Apocalypse d'Abraham. Introduction, texte slave, traduction et notes, 46.

17 Kulik, Retroverting Slavonic Pseudepigrapha, 13.

18 It should be noted that the Book of Daniel and the Book of Revelation refer to fiery feet of not only divine but also angelic manifestations: Dan 10:5-6: "I looked up and saw a man clothed in linen, with a belt of gold from Uphaz around his waist. His body was like beryl, his face like lightning, his eyes like flaming torches, his arms and legs like the gleam of burnished bronze, and the sound of his words like the roar of a multitude." Rev 10:1: "And I saw another mighty angel coming down from heaven, wrapped in a cloud, with a rainbow over his head; his face was like the sun, and his legs like pillars of fire...."

19 This tradition is then reaffirmed in Rev 2:18 "These are the words of the Son of God, who has eyes like a flame of fire, and whose feet are like burnished bronze..."

${ }^{20}$ Kulik, Retroverting Slavonic Pseudepigrapha, 12.

Journal for the Study of the Pseudepigrapha, Vol. 18, No. 1 (2008): pg. 33-53. DOI. This article is C SAGE Publications and permission has been granted for this version to appear in e-Publications@ Marquette. SAGE Publications does not grant permission for this article to be further copied/distributed or hosted elsewhere without the express permission from SAGE Publications. 
NOT THE PUBLISHED VERSION; this is the author's final, peer-reviewed manuscript. The published version may be accessed by following the link in the citation at the bottom of the page.

${ }^{21}$ L. Ginzberg, "Abraham, Apocalypse of," Jewish Encyclopedia (New York, 1906) 1.91-92.

22 A. Kulik, "The Gods of Nahor: A Note on the Pantheon of the Apocalypse of Abraham," JJS 54 (2003) 228-232; idem, Retroverting Slavonic Pseudepigrapha, 63.

23 On the fwv traditions see G. Quispel, "Ezekiel 1:26 in Jewish Mysticism and Gnosis," VC 34 (1980) 1-13 at 6-7; J. Fossum, The Name of God and the Angel of the Lord: Samaritan and Jewish Mediation Concepts and the Origin of Gnosticism (WUNT 36; Tübingen: Mohr/Siebeck, 1985) 280; idem, The Image of the Invisible God: Essays on the Influence of Jewish Mysticism on Early Christology (NTOA 30; Fribourg: Universitätsverlag Freiburg Schweiz; Göttingen: Vanderhoeck \& Ruprecht, 1995) 16-17; S. N. Bunta, Moses, Adam and the Glory of the Lord in Ezekiel the Tragedian: On the Roots of a Merkabah Text (Ph.D. Dissertation; Marquette University, 2005) 92ff.

24 B. Philonenko-Sayar and M. Philonenko, L'Apocalypse d'Abraham. Introduction, texte slave, traduction et notes, 88.

${ }^{25}$ Bunta, Moses, Adam and the Glory of the Lord in Ezekiel the Tragedian, 111-112.

${ }^{26}$ For the discussion of the terminological interplay \#) /\#y) in Ezek 8:2, see Bunta, Moses, Adam and the Glory of the Lord in Ezekiel the Tragedian, 111.

27 One such development is the repeated portrayal of Terah fashioning idols in the manner similar to the Genesis' depictions of the Deity fashioning the Protoplast.

28 Kulik, Retroverting Slavonic Pseudepigrapha, 15.

${ }^{29}$ See Apoc. Ab. 18:2; 18:3; 18:12; 19:4; 19:6.

30 See $A$ poc. Ab. 8:1; 18:2.

31 Dan 3:25 Nyhl) rbl hmd (like a son of the gods").

${ }^{32}$ C.L. Seow, Daniel (Westminster Bible Companion; Westminster John Knox Press: Louisville, 2003) 59.

33 Seow, Daniel, 60.

34 Seow, Daniel, 59.

352 Enoch 22 serves as an early attestation to this tradition. We can find a detailed description of this process in another "Enochic" text, Sefer Hekhalot, which describes the transformation of Enoch-Metatron, the Prince of the Divine Presence, into the fiery representation serving as a replica of the divine corporeality: "R. Ishmael said: The angel Metatron, Prince of the Divine Presence, the glory of highest heaven, said to me: When the Holy One, blessed be he, took me to serve the throne of glory, the wheels of the chariot and all needs of the Shekinah, at once my flesh turned to flame, my sinews to blazing fire, my bones to juniper coals, my eyelashes to lightning flashes, my eyeballs to fiery torches, the hairs

Journal for the Study of the Pseudepigrapha, Vol. 18, No. 1 (2008): pg. 33-53. DOI. This article is (C SAGE Publications and permission has been granted for this version to appear in e-Publications@Marquette. SAGE Publications does not grant permission for this article to be further copied/distributed or hosted elsewhere without the express permission from SAGE Publications. 
NOT THE PUBLISHED VERSION; this is the author's final, peer-reviewed manuscript. The published version may be accessed by following the link in the citation at the bottom of the page.

of my head to hot flames, all my limbs to wings of burning fire, and the substance of my body to blazing fire." 3 Enoch 15:1. Alexander, 3 Enoch, 267.

${ }^{36}$ Another proof that the fiery test in the apocalyptic account of Abraham's fight against idols might be informed by the Danielic traditions can be supported by the pseudepigraphical and rabbinic testimonies attested in the Biblical Antiquities of Pseudo-Philo 6:5-18; Genesis Rabbah 38:13, Tanna debe Eliahu 2:25, Seder Eliahu Rabba 33 where similar to Barisat and Daniel the patriarch himself undergoes the fiery test which he unlike the wooden idol successfully passes. Genesis Rabbah 38:13 reads: "And Haran died in the presence of his father Terah (xi, 28). R. Hiyya said: Terah was a manufacturer of idols. He once went away somewhere and left Abraham to sell them in his place. A man came and wished to buy one. "How old are you?" Abraham asked him. "Fifty years," was the reply. "Woe to such a man!" he exclaimed, "you are fifty years old and worship a day-old object!" At this he became ashamed and departed. On the other occasion a woman came with a plateful of flour and requested him, "Take this and offer it to them." So he took a stick, broke them, and put the stick in the hand of the largest. When his father returned he demanded, "What have you done to them?" "I cannot conceal it from you," he rejoined. "A woman came with a plateful of fine meal and requested me to offer it to them. One claimed, 'I must eat first,' while another claimed, 'I must eat first.' Therefore the largest arose, took the stick, and broke them." "Why do you make sport of me," he cried out; "have they then any knowledge!" "Should not your ears listen to what your mouth is saying," he retorted. Thereupon he seized him and delivered him to Nimrod. "Let us worship the fire!" he [Nimrod] proposed. "Let us rather worship water, which extinguishes the fire," replied he. "Then let us worship water!" "Let us rather worship the clouds which bear the water." "Then let us worship the cloud!' "Let us rather worship the winds which disperse the clouds." "Then let us worship the wind!" "Let us rather worship human beings, who withstand the wind." "You are just bandying words," he exclaimed; "we will worship nought but the fire. Behold, I will cast you into it, and let your God whom you adore come and save you from it." Now Haran was standing there undecided. If Abram is victorious, [thought he], I will say that I am of Abram's belief, while if Nimrod is victorious I will say that I am on Nimrod's side. When Abram descended into the fiery furnace and was saved, he [Nimrod] asked him, "Of whose belief are you?" "Of Abram's," he replied. Thereupon he seized and cast him into fire; his inwards were scorched and he died in his father's presence. Hence it is written, and Haran died in the presence of (cal pene) his father Terah." Midrash Rabbah, 1.310-311.

Journal for the Study of the Pseudepigrapha, Vol. 18, No. 1 (2008): pg. 33-53. DOI. This article is C SAGE Publications and permission has been granted for this version to appear in e-Publications@Marquette. SAGE Publications does not grant permission for this article to be further copied/distributed or hosted elsewhere without the express permission from SAGE Publications. 
${ }^{37}$ Apoc. Ab. 8:6 "...when the sound of thunder came forth and burned him and his house and everything in the house, down to the ground [to a distance of] forty cubits." Kulik, Retroverting Slavonic Pseudepigrapha, 16. Jub. 12:14 "... Haran dashed in to save them, but the fire raged over him. He was burned in the fire and died in Ur of the Chaldeans before his father Terah. They buried him in Ur of the Chaldeans." VanderKam, The Book of Jubilees, 2. 70.

38 The tendency to substitute anthropomorphic depictions of the Deity with expressions of the divine Voice manifesting itself in the fire, of course, is not a novel development of the Apocalypse of Abraham authors, but a specimen of the long-lasting tradition whose roots can be found already in the Book of Deuteronomy. Scholars have long noted a sharp opposition of the book of Deuteronomy and the deuteronomic school to early anthropomorphic developments. In fact, the Deuteronomic school is widely thought to have initiated the polemic against the anthropomorphic and corporeal conceptions of the Deity, which were subsequently adopted by the prophets Jeremiah and Deutero-Isaiah. Seeking to dislodge ancient anthropomorphism, the book of Deuteronomy and the deuteronomic school promulgated anti-corporeal theology of the divine Name with its conception of sanctuary (tabernacle) as the exclusive dwelling abode of God's name. One can see in the deuteronomic school a paradigm shift of the revelatory axis from the visual to the aural plane. In this new, theo-aural, as opposed to theo-phanic, understanding, even God's revelation to Moses on Mt. Sinai in Exodus 19, an event marking a vital nexus of the visual anthropomorphic paradigm, becomes reinterpreted in the terms of its aural counterpart. Deuteronomy 4:36 describes the Sinai theophany as a hearing of the divine Voice: "Out of heaven he let you hear his voice, that he might discipline you; and on earth he let you see his great fire and you heard his words out of the midst of the fire." On the formative role of the Deuteronomic tradition for the theophanic imagery of the Apocalypse of Abraham, see Orlov, "Praxis of the Voice," 58-60.

${ }^{39}$ Kulik, Retroverting Slavonic Pseudepigrapha, 15.

${ }^{40}$ Rubinkiewicz, L'Apocalypse d'Abraham en vieux slave. Édition critique $d u$ texte, introduction, traduction et commentaire, 114.

${ }^{41}$ See also 6:18 "Today I shall create (сътворю) another one...." Rubinkiewicz, L'Apocalypse d'Abraham en vieux slave. Édition critique du texte, introduction, traduction et commentaire, 116.

42 Kulik, Retroverting Slavonic Pseudepigrapha, 9.

43 The term dwbk can be also translated as "substance," "body," "mass," "power," "might," "honor," "glory," "splendor." In its meaning "glory" dwbk usually refers to God, his sanctuary, his city, or sacred paraphernalia. The Priestly tradition uses the term in connection with permission has been granted for this version to appear in e-Publications@Marquette. SAGE Publications does not grant permission for this article to be further copied/distributed or hosted elsewhere without the express permission from SAGE Publications. 
NOT THE PUBLISHED VERSION; this is the author's final, peer-reviewed manuscript. The published version may be accessed by following the link in the citation at the bottom of the page.

God's appearances in the tabernacle. P and Ezekiel describe dwbk as a blazing fire surrounded by radiance and a great cloud. M. Weinfeld, "dwbk," TDOT, 7.22-38.

44 The Slavonic noun "тягота" (Арос. $A b .14: 13$ ) is derived from the same root as the adjective "тяжекъ" (Аpoc. $A b .1: 4)$.

45 Rubinkiewicz, L'Apocalypse d'Abraham en vieux slave. Édition critique $d u$ texte, introduction, traduction et commentaire, 150.

46 Rubinkiewicz points to the presence of the formulae in Lk 4:6 "I will give you all their authority and splendor..."

47 Kulik, Retroverting Slavonic Pseudepigrapha, 29. B. Philonenko-Sayar and M. Philonenko, L'Apocalypse d'Abraham. Introduction, texte slave, traduction et notes, 92.

48 B. Philonenko-Sayar and M. Philonenko, L'Apocalypse d'Abraham. Introduction, texte slave, traduction et notes, $92 .{ }^{49}$ On this issue see $\mathrm{R}$. Elior, The Three Temples: On the Emergence of Jewish Mysticism (Oxford: Littman Library of Jewish Civilization, 2004). ${ }^{50}$ For a discussion of this tradition, see Orlov, The Enoch-Metatron Tradition, 70-76.

Journal for the Study of the Pseudepigrapha, Vol. 18, No. 1 (2008): pg. 33-53. DOI. This article is C SAGE Publications and permission has been granted for this version to appear in e-Publications@ Marquette. SAGE Publications does not grant permission for this article to be further copied/distributed or hosted elsewhere without the express permission from SAGE Publications. 